\title{
Occurrence and Habitat Characteristics of Aurelia sp. Polyps in a High-Latitude Fjord
}

\author{
Matias Einer Rekstad, Sanna Majaneva, Åshild Løvas Borgersen and Nicole Aberle* \\ Norwegian University of Science and Technology (NTNU), Trondhjem Biological Station, Department of Biology, Trondheim, \\ Norway
}

OPEN ACCESS

Edited by:

Ulisses Miranda Azeiteiro, University of Aveiro, Portugal

Reviewed by:

Yantao Wang,

Institute of Oceanology, Chinese Academy of Sciences (CAS), China

Cathy Lucas,

University of Southampton,

United Kingdom

${ }^{*}$ Correspondence:

Nicole Aberle

nicole.aberle-malzahn@ntnu.no

Specialty section

This article was submitted to

Marine Ecosystem Ecology,

a section of the journal

Frontiers in Marine Science

Received: 23 March 2021

Accepted: 28 May 2021

Published: 24 June 2021

Citation:

Rekstad ME, Majaneva S, Borgersen ÅL and Aberle N (2021)

Occurrence and Habitat Characteristics of Aurelia sp. Polyps

in a High-Latitude Fjord.

Front. Mar. Sci. 8:684634.

doi: 10.3389/fmars.2021.684634
Causes and consequences of jellyfish bloom formation are subject to controversial discussions worldwide. While medusae have been studied to a broader extent, the knowledge on polyp stages of scyphozoans is limited thus hampering reliable prediction of jellyfish bloom formation. This study describes the occurrence, abundance, habitat characteristics and interactions of scyphozoan Aurelia sp. polyp colonies with other fouling organisms in intertidal and subtidal sectors of Trondheimsfjorden (Norway). In total, 982 polyps were found on 70 substrata of varying material types during a field survey in spring-summer 2018 along a longitudinal gradient within and outside Trondheimsfjorden. The polyps were identified as Aurelia sp. based on molecular species identification. Most polyps were found in bays with macroalgae canopy on the down facing side of artificial and natural substrata (rocks, concrete, iron) and inside rock cracks. Polyp microhabitats included the surface of Ascidia mentula (solitary ascidian), increments of Pomatoceros triqueter (polychete) tubes and dead Balanus balanoides (barnacle) shells. Based on the deployment of settling plates, abundance of Aurelia sp. polyps ranged from $1.2( \pm 0.7)$ to $0.12( \pm 0.07)$ polyps $\mathrm{cm}^{-2}$. Settlement occurred either directly on the PVC settling plates or as epibionts on the ascidian Ascidia mentula and on barnacle shells of Balanus balanoides. This study provides insights into the potential of local Aurelia sp. polyps contributing to the seasonal occurrence and abundance of Aurelia sp. in fjord systems, where intensive blooms occur annually.

Keywords: scyphozoa, scyphopolyp, fjord, artificial substrata, scyphistoma, polyp settlement, polyp habitat

\section{INTRODUCTION}

Jellyfish blooms vary from weekly changes to decadal cycles (Lucas et al., 2012; Hosia et al., 2014; Licandro et al., 2015). The frequency and intensity of blooms can restructure pelagic food-webs, clog electrical power plant passages, and impact fisheries, aquaculture and tourism (Doney et al., 2012; Doyle et al., 2014; Graham et al., 2014; Dong, 2018; Halsband et al., 2018).

The cosmopolitan scyphozoan genus Aurelia has adapted to a broad range of hydrographic conditions in coastal and shelf marine environments (Lucas, 2001). Aurelia sp. has a metagenetic life cycle, alternating between pelagic (ephyrae, sexually reproducing medusae, planulae) and benthic (asexually reproducing polyps/scyphistoma, podocysts, planulocysts) stages (Arai, 1997). Aurelia aurita can produce 1-18 ephyra per strobila within 18-60 days after settlement (Lucas et al., 2012).

Over the last decades, benthic scyphozoan life stages as drivers of jellyfish blooms have received more attention (Marcus, 1998; Lucas et al., 2012; Duarte et al., 2013). Reports on the occurrence 
of scyphozoan polyps on a variety of natural and artificial substrata is available for coastal marine systems in Europe, North America, and South-East Asia (Lucas, 2001; Dong, 2018). However, a clear taxonomic identification of the polyps in situ is often not provided due to constraints of morphological identification (Holst, 2012; van Walraven et al., 2016). Despite these shortcomings, only few studies used molecular tools for taxonomic identification of polyps in the field so far (van Walraven et al., 2016, 2020).

In situ observations and studies on habitat characteristics of polyps in fjord ecosystems are rare. To our knowledge, only one study exists that studied respiratory responses of Aurelia polyps of high latitude fjord populations (Hoehn et al., 2017). This is astonishing since seasonal blooms of scyphomedusae frequently occur in high latitude fjords. As an example, blooms of Aurelia sp. medusae are common in Trondheimsfjorden during summertime (June-September). In the summer periods 2018 to 2020, relatively constant Aurelia sp. biomass were observed in Trondheimsfjorden with catch-per-unit-efforts (CPUE) of $82.4 \mathrm{~kg}^{-1} \mathrm{~h}^{-1}$ (2018), $70.6 \mathrm{~kg}^{-1} \mathrm{~h}^{-1}$ (2019) and $88.2 \mathrm{~kg}^{-1} \mathrm{~h}^{-1}$ (2020) based on trawling efforts (ongoing project activities, EUproject GoJelly).

Fjords provide unique ecosystem services and the impacts of jellyfish blooms on the trophic structure, interference with local fisheries and potential constraints for tourism are intensively discusses in the media. So far, our knowledge on the origin of such blooms is limited but, from a management perspective, it matters whether the blooms of scyphomedusae originate from local polyp populations or are advected into a given fjord ecosystem from adjacent water bodies. Only if the origin of seed populations can be localized, ecosystem-based management approaches can be developed thus allowing more reliable prediction on jellyfish bloom occurrence in a given ecosystem. To date, there is a considerable lack of information on the occurrence and abundance of benthic scyphozoan life stages that determine the intensity and frequency of local jellyfish bloom population in fjord ecosystems. More knowledge is needed to allow future predictions on local bloom scenarios.

For the recruitment of local populations, the timing of the planulae release is a crucial step of the reproduction. In temperate waters, planulae release is usually considered as an annual event that occurs between 1 and 5 months over the summer period (Gröndahl, 1988a; Lucas et al., 2012). However, the occurrence and habitat characteristics of Aurelia sp. polyps remain unknown. In general, polyps are considered to preferentially settle in shaded and sheltered environments on the down facing side of rough substrata (Brewer, 1984; Östman, 1997; van Walraven et al., 2016). They have been found on various types of natural and artificial substrata like wood, granite, glass, polymers, iron and natural substrata like rocks, mussels, barnacles, ascidians, polychetes, and macroalgae (Holst and Jarms, 2007; Lucas et al., 2012; van Walraven et al., 2016, 2020; Feng et al., 2017a) while artificial substrata such as concrete, machined wood, polyethylene and glass seem to be preferred over natural substrata like mussel shells (Holst and Jarms, 2007; Hoover and Purcell, 2008; Janssen et al., 2013; Marques et al., 2015). In this context, the introduction of artificial substrata due to coastal development (e.g., aquaculture rigs, marinas, wind parks) has caused additional concern since this could further promote jellyfish blooms especially in semi-enclosed or enclosed ecosystems (Holst and Jarms, 2007; Duarte et al., 2013; Makabe et al., 2014).

Mortality of planulae and polyps is considered as a crucial factor affecting scyphomedusae abundances and inter-annual variations (Gröndahl, 1988b). Optimal substrata for a successful planulae settlement and polyp survival thus directly affect scyphomedusae bloom formation (Holst and Jarms, 2007; Ishii and Katsukoshi, 2010). Information on biotic interactions between polyps and other fouling organisms is scarce. However, direct competition for space between polyps and other fouling organisms such as mussels, barnacles, polychetes and ascidians seems likely (Ishii et al., 2008; Lucas et al., 2012; Feng et al., 2017b). As an example, inter-specific competition for space was reported between $A$. aurita polyps that colonized the benthic layers close to the bottom in Tokyo Bay, Japan, while the blue mussel Mytilus galloprovincialis was found on surfaces in the uppermost layers. This pattern was most likely related to a better tolerance of $A$. aurita polyps to hypoxic conditions.

To our knowledge, this is the first study focusing on the occurrence and habitat characteristics of Aurelia sp. polyps in a high-latitude fjord ecosystem. While few sightings of polyps were reported from e.g., the littoral zones of Trondheimsfjorden earlier (Tokle and Sakshaug, 2000), information on specific habitat characteristics and substratum preferences (substratum type, artificial vs. natural surfaces) from in situ observations is not available thus limiting our knowledge on potential local bloom formation of Aurelia sp. in high-latitude fjord ecosystems. The present study aimed to analyze the role of specific microand macrohabitats on the occurrence of local Aurelia sp. polyp populations and the impact of biotic conditions and interactions between polyps and other fouling organisms. Macrohabitats in sheltered and exposed environments including macroalgae canopies were analyzed for polyp occurrence followed by a more detailed view on the impact of microhabitats created by other fouling organisms on polyp settlement.

Several hypotheses were addressed:

H1: Polyps of Aurelia sp. are common fouling organisms in the littoral zones of a high-latitude fjord.

$\mathrm{H} 2$ : Sheltered and exposed macrohabitats serve equally as suitable environments for Aurelia sp. polyps.

H3: Microhabitats created by other fouling organisms promote a suitable environment for Aurelia sp. polyps.

H4: Natural surfaces are preferred substrata of Aurelia sp. polyps over artificial surfaces.

\section{MATERIALS AND METHODS}

\section{Study Area}

The study was conducted along a longitudinal gradient in Trondheimsfjorden, from the innermost part of the fjord to the outermost part of Trondheimsleia (Figure 1). 


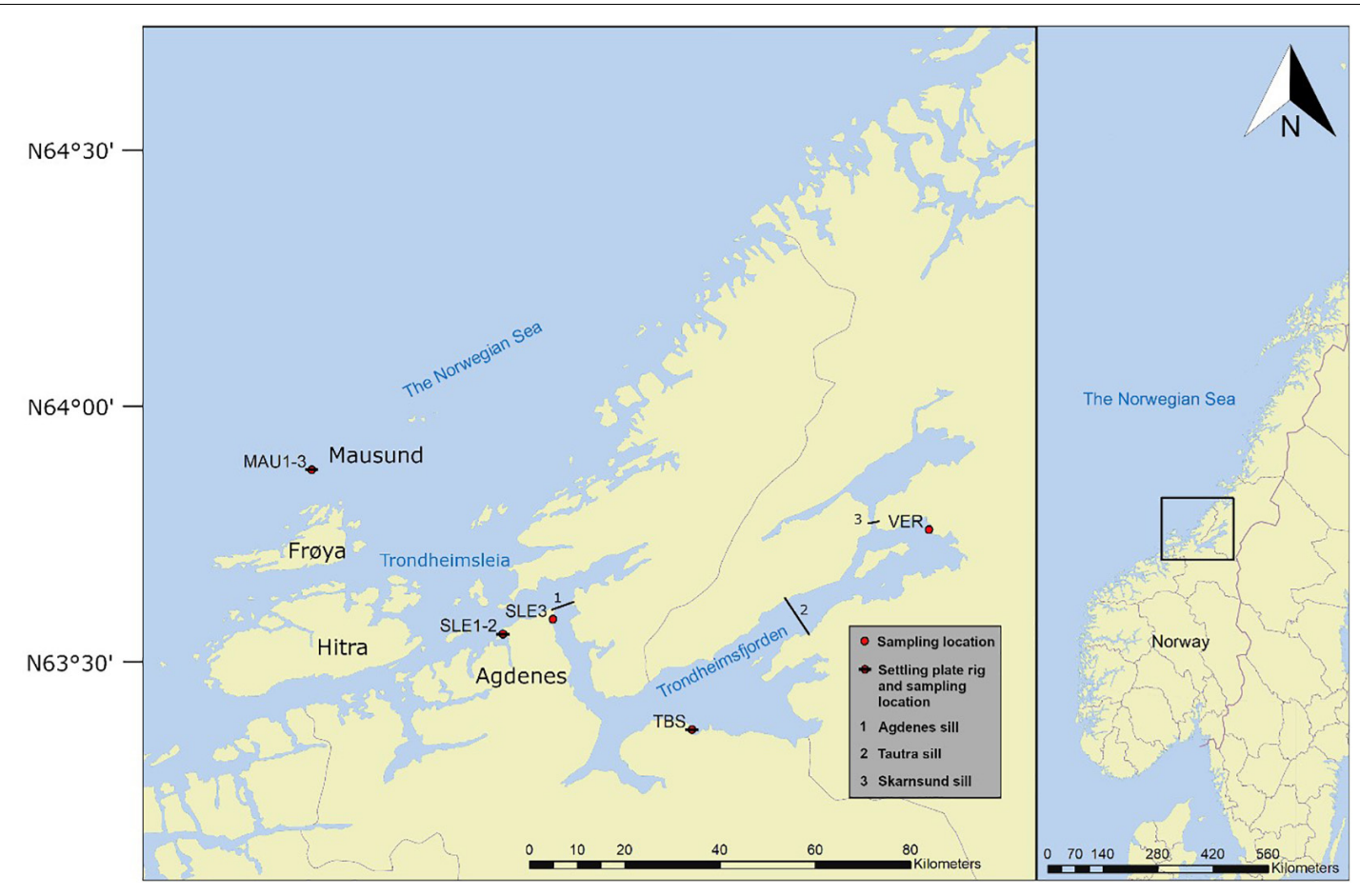

FIGURE 1 | Trondheimsfjorden and the island group Hitra, Frøya, and Mausund. Settling plate rigs were deployed at MAU1, SLE1, and TBS. Field survey was conducted at MAU1-3, SLE1-3, TBS, and VER.

Trondheimsfjorden is situated on the Norwegian west coast (Latitude: $63^{\circ} 29^{\prime} 59.99^{\prime \prime} \mathrm{N}$, Longitude: $\left.10^{\circ} 27^{\prime} 59.99^{\prime \prime} \mathrm{E}\right)$. The fjord is $126 \mathrm{~km}$ long with a volume of $235 \mathrm{~km}^{2}$ and an average depth of $165 \mathrm{~m}$. There are three main sills in Trondheimsfjorden (1) Agdenes sill (195 $\mathrm{m}$ depth) separating the fjord from the Norwegian Sea, (2) Tautra sill (100 m depth), and (3) Skarnsund sill (140 $\mathrm{m}$ depth) that divide the fjord into three basins (Bakken, 2000). Water mixing in Trondheimsfjorden is affected by wind, river run-off, tidal energy and inflow from the North Atlantic and the Norwegian coastal current. The inflowing water replaces the bottom water in the deep basins usually twice a year (Jacobson, 1983).

At the entrance to the fjord, the straight Trondheimsleia is located between the mainland and the islands Hitra, Frøya, and Mausund. In contrast to Trondheimsleia and Trondheimsfjorden, the islands are exposed to strong currents, waves and wind.

\section{Field Survey}

Sampling of polyps occurred along a longitudinal gradient from the outermost to the innermost part of Trondheimsfjorden during a period from mid-March to late May 2018 (Table 1). Medusae of Aurelia aurita usually appear in Trondheimsfjorden from June to September. Spawning A. aurita medusae occur in late summer/beginning of autumn followed by a release of planulae in the water column. Strobilation and ephyrae release were observed at different locations in the fjord during the period from March to May (Rekstad, Borgersen, Aberle pers. observation). Ephyrae were not collected in the water column of Trondheimsfjorden despite several WP2/WP3 vertical net deployments during different seasons and at several locations in the fjord (unpublished data, EU-project GoJelly).

Habitats that were previously reported as suitable for polyps (e.g., sheltered bays with macroalgae canopy or hard substratum with suitable microhabitats) (Östman, 1997; Lucas et al., 2012; van Walraven et al., 2016) were taken into consideration. Four stations with different substratum and vegetation types and different degrees of exposure to currents and wave action were chosen: Mausund (MAU1-3), Agdenes (SLE1-3), Trondhjem Biological Station (TBS), and Verdal (VER). All locations are affected by the Norwegian Coastal Current that originates from the North Atlantic Drift mixed with inputs from the Baltic Sea and the North Sea. Sea surface temperature range from $3-5^{\circ} \mathrm{C}$ in winter to $14-17^{\circ} \mathrm{C}$ in summer (Sakshaug and Sneli, 2000). Ice formation is rare. Surface water salinity ranges from 34.5. During spring/summer, freshwater run-off leads to a decrease in salinity down to 27, especially in the inner part of the fjord (locations TBS and VER). Tidal currents along the longitudinal gradient from the outer to the inner part of the fjord vary from 70 to $100 \mathrm{~cm} \mathrm{~s}^{-1}$.

Randomly selected artificial and natural hard substrata (in total > 100 different substrata) were screened in the interand sub-tidal areas along the Trondheimsfjorden shoreline for the presence of polyps on different substrata (Table 1). Hard substrata were fully or partially submersed in seawater and sampled from the intertidal and shallow sub-tidal $(0.1$ to $3 \mathrm{~m}$ depth below the LWL) by snorkeling and wading. The substrata were checked for polyp presence on site by placing pieces of substratum in transparent plastic containers filled with seawater 
TABLE 1 | Results from the field survey.

\begin{tabular}{|c|c|c|c|c|c|c|c|c|c|}
\hline Station & Coordinates & Depth (m) & Date & $\begin{array}{l}\text { Substratum } \\
\text { type }\end{array}$ & $\begin{array}{l}\text { Number of } \\
\text { substrata }\end{array}$ & $\begin{array}{c}\text { Number of } \\
\text { polyps }\end{array}$ & $\begin{array}{c}\text { Number of } \\
\text { strobile }\end{array}$ & $\begin{array}{c}\text { Mean polyp/ } \\
\text { strobila size }(\mathrm{mm})\end{array}$ & $\begin{array}{l}\text { Polyp species } \\
\text { (BLAST results) }\end{array}$ \\
\hline MAU1 & $\begin{array}{l}63^{\circ} 52^{\prime} 34.23^{\prime \prime} \\
8^{\circ} 38^{\prime} 29.07^{\prime \prime}\end{array}$ & 1 & 10.04 .2018 & Rock & 3 & 53 & 24 & - & Aurelia aurita * \\
\hline MAU2 & $\begin{array}{l}63^{\circ} 51^{\prime} 23.66^{\prime \prime} \\
8^{\circ} 38^{\prime} 34.62^{\prime \prime}\end{array}$ & $0.2-2$ & 29.05 .2018 & Rock & 3 & 103 & 0 & $1.48( \pm 0.57)$ & Aurelia aurita (5) \\
\hline MAU3 & $\begin{array}{l}63^{\circ} 52^{\prime} 39.26^{\prime \prime} \\
8^{\circ} 37^{\prime} 56.08^{\prime \prime}\end{array}$ & 0.4 & 29.05.2018 & Kelp & 2 & 23 & 0 & $1.00( \pm 0.00)$ & Aurelia aurita (3) \\
\hline \multirow[t]{10}{*}{ SLE1 } & $\begin{array}{l}63^{\circ} 35^{\prime} 34.98^{\prime \prime} \\
9^{\circ} 32^{\prime} 23.28^{\prime \prime}\end{array}$ & $1-2$ & 14.03 .2018 & Brick & 3 & 14 & 5 & $1.18( \pm 0.44)$ & Aurelia aurita (4) \\
\hline & & & & Rock & 1 & 6 & 5 & & \\
\hline & & & & Glass bottle & 1 & 4 & 3 & & \\
\hline & & & & Iron plate & 1 & 24 & 0 & & \\
\hline & & & & $\begin{array}{l}\text { Substratum } \\
\text { total }\end{array}$ & 6 & 48 & 13 & & \\
\hline & & $1-2$ & 12.04 .2018 & Brick & 3 & 20 & 0 & & Aurelia aurita (4) \\
\hline & & & & $\begin{array}{l}\text { Cinder } \\
\text { block }\end{array}$ & 3 & 71 & 0 & & $\begin{array}{l}\text { Aurelia aurita (5); } \\
\text { Aurelia sp. (4) }\end{array}$ \\
\hline & & & & Rock & 1 & 3 & 0 & & Aurelia aurita (1) \\
\hline & & & & $\begin{array}{l}\text { Substratum } \\
\text { total }\end{array}$ & 7 & 94 & 0 & & \\
\hline & & 1 & 30.05 .2018 & Rock & 5 & 36 & 0 & $1.43( \pm 0.69)$ & $\begin{array}{l}\text { Aurelia aurita (4); } \\
\text { Aurelia sp. (1) }\end{array}$ \\
\hline SLE1 (b) & & 0.5 & 13.04 .2018 & Rock & 1 & 2 & 0 & & Aurelia aurita (2) \\
\hline SLE2 & $\begin{array}{l}63^{\circ} 37^{\prime} 32.21^{\prime \prime} \\
9^{\circ} 44^{\prime} 29.33^{\prime \prime}\end{array}$ & $0.5-1$ & 31.05 .2018 & Rock & 4 & 66 & 0 & $0.5( \pm 0.0)$ & $\begin{array}{l}\text { Aurelia aurita (5); } \\
\text { Aurelia sp. (7) }\end{array}$ \\
\hline SLE3 & $\begin{array}{l}63^{\circ} 36^{\prime} 41.37^{\prime \prime} \\
9^{\circ} 34^{\prime} 36.62^{\prime \prime}\end{array}$ & $0.2-1$ & 13.04 .2018 & Rock & 2 & 39 & 16 & $1.00( \pm 0.47)$ & \\
\hline \multirow[t]{5}{*}{ TBS } & $\begin{array}{l}63^{\circ} 26^{\prime} 25.41^{\prime \prime} \\
10^{\circ} 20^{\prime} 54.83^{\prime \prime}\end{array}$ & $0.2-0.5$ & 06.04 .2018 & Rock & 4 & 80 & 13 & & Aurelia aurita (2) \\
\hline & & & & Concrete & 1 & 15 & 5 & & \\
\hline & & & & $\begin{array}{l}\text { Substratum } \\
\text { total }\end{array}$ & 5 & 95 & 18 & & \\
\hline & & & 04.05 .2018 & Rock & 1 & 30 & 0 & $0.96( \pm 0.53)$ & Aurelia aurita (3) \\
\hline & & & 25.05 .2018 & Rock & 2 & 81 & 0 & & \\
\hline \multirow[t]{2}{*}{ VER } & $\begin{array}{l}63^{\circ} 51^{\prime} 3.18^{\prime \prime} \\
11^{\circ} 18^{\prime} 16.41^{\prime \prime}\end{array}$ & $0.1-1$ & 15.03 .2018 & Rock & 17 & 214 & 27 & & Aurelia aurita (6) \\
\hline & & $0.1-1.5$ & 02.05.2018 & Rock & 7 & 98 & 6 & $0.57( \pm 0.18)$ & Aurelia aurita (3) \\
\hline
\end{tabular}

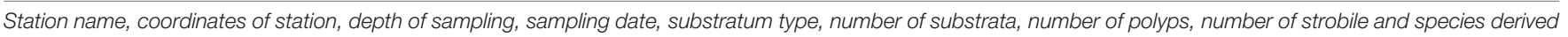

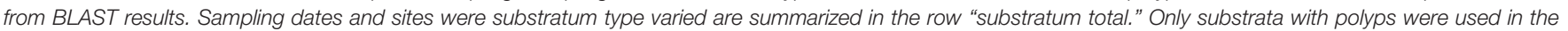
dataset. Number of substrata does not equal the number of substrata examined. *Indicates released ephyrae from strobile.

to inspect for polyp occurrence on-site. On each substratum, individual polyps were counted and the substratum type noted. Only substrata with polyps attached were included in the dataset.

Random polyp individuals were selected from the substratum (max. up to 30 individuals per station, polyp length ranging from 0.5 to $2 \mathrm{~mm}$ from the base to the oral region) and fixed in ethanol (96\%) for molecular species identification.

Hoop plots were chosen by throwing a hula-hoop-ring $(\varnothing$ $1 \mathrm{~m}$ ) with weights attached randomly 3-4 times in each area to assess habitat characteristics and biotic conditions. Species observed inside each hoop plot were identified to the lowest possible taxonomic level or functional group. The relative abundance of each species inside the hoop was estimated relative to the percentage of coverage and divided into the following levels: 1 (very low, less than 10\%), 2 (low, less than 20\%) 3 (moderate, 30-50\%), 4 (high, 50-70\%), 5 (very high, 70-100\%). The original hoop plot protocol to document absolute abundance data needed to be refined due to time-constraints and logistical challenges during the short low-tide period thus resulting in relative abundance data.

\section{Settling Plate Survey}

Settling plates [SETL design of van Walraven et al. (2016)] were deployed from mid-March to mid-April 2018 at MAU1, SLE1, and TBS (Table 2). These plates were attached to bricks that were tied to a rig system containing in total six settling plate units. The units were constructed using bricks $(285 \mathrm{~mm} \times 85 \mathrm{~mm} \times 85 \mathrm{~mm})$, PVC plates $(140 \mathrm{~mm} \times 140 \mathrm{~mm} \times 5 \mathrm{~mm})$ and zip ties and moored to the rigs from floats at 1 and $3 \mathrm{~m}$ depth (appr. $1 \mathrm{~m}$ between each 
TABLE 2 | Station, depth, and retrieval date of the settling plate rigs.

\begin{tabular}{|c|c|c|c|c|c|c|}
\hline Station & Depth (m) & Deployment date & Retrieval date & $\begin{array}{l}\text { Mean polyp abundance ( } \\
\mathrm{cm}^{-2} \pm \mathrm{SD} \text { ) }\end{array}$ & $\begin{array}{l}\text { Number of individual polyps } \\
\text { on specific substrata }\end{array}$ & $\begin{array}{l}\text { Polyp species (\# } \\
\text { BLAST results) }\end{array}$ \\
\hline \multirow[t]{2}{*}{ MAU1 } & 1 & 09.04 .18 & 10.10 .18 & 0 & & \\
\hline & 3 & & & 0 & & \\
\hline \multirow[t]{4}{*}{ SLE1 } & 1 & 13.03.18 & 19.09 .18 & 0 & & \\
\hline & 3 & & & $1.2( \pm 0.7)$ & PVC plate (88) & Aurelia aurita (25) \\
\hline & & & & & A. mentula (12) & \\
\hline & & & & & C. intestinalis $(0.1)$ & \\
\hline \multirow[t]{6}{*}{ TBS } & 1 & 23.03 .18 & 25.09 .18 & $0.4( \pm 0.5)$ & PVC plate (79) & Aurelia aurita (13) \\
\hline & & & & & B. balanoides (21) & \\
\hline & & & & & M. edulis $(0.6)$ & \\
\hline & 3 & & & $0.12( \pm 0.07)$ & PVC plate (74) & Aurelia aurita (18) \\
\hline & & & & & B. balanoides (22) & \\
\hline & & & & & M. edulis (4) & Aurelia sp. (1) \\
\hline
\end{tabular}

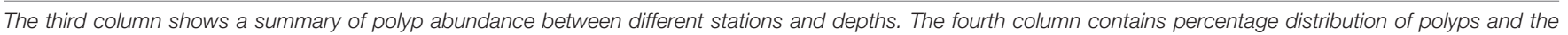
different substrata. The fifth column contains the most likely species match from BLAST sequence comparison and the number of matches.

float), with three replicates each at 1 and $3 \mathrm{~m}$ depth (Figure 2). Examination of the units were performed monthly from April to October 2018 using in situ snorkeling and underwater photography (Table 2). During examination, the settling plates were analyzed for presence/absence of polyps. The fouling organisms were identified to the lowest possible taxonomic level or functional group and their relative share compared to the total coverage on the brick or PVC plate from 0 (none) to 5 (very high) was documented. The plates remained fully submerged during examination. After the first observation of polyps at SLE1 in September, the remaining settling rigs (MAU1, TBS) were subsequently retrieved and processed within the next 4 weeks. Each settling plate was screened for a final assessment of fouling organisms and polyps at the different stations. Fouling coverage and taxonomic composition was documented during the final examination using photography and percentage coverage on the settling plate calculated using ImageJ 1.8.0 software (Abramoff et al., 2004). All species where treated as a single layer on a two-dimensional plane, even though some plates (TBS) had several layers of species. As an example, a mixture of dead barnacles and live/dead mussels was treated as one layer and one variable ("Debris mix"). The polyps were counted using stereo microscopy (1-16 $\times$ magnification). Random polyp individuals (up to 30 individuals per station, polyp length ranging between 0.5 and $2 \mathrm{~mm}$ ) were sampled from each plate and fixed in ethanol (96\%) for molecular species identification.

\section{DNA Extraction and Sequencing}

DNA was extracted from randomly selected 121 out of 270 field survey polyps and 72 out of 195 settling plate polyps taking different sampling locations and, substrata into account. DNA was extracted from small piece or whole specimen with a modified Chelex rapid-boiling procedure as explained in Granhag et al. (2012). Cytochrome c oxidase subunit 1, mtCOI (app. 500-600 bp) amplifications were performed with scyphozoan specific primers ScyCOIf and ScyCOIr (van Walraven et al., 2016) with $5 \mathrm{~min}$ at $98^{\circ} \mathrm{C}$, followed by 40 cycles of $10 \mathrm{~s}$ at $60^{\circ} \mathrm{C}, 1 \mathrm{~min}$ at $72^{\circ} \mathrm{C}$ and finally $5 \mathrm{~min}$ at $72^{\circ} \mathrm{C}$. PCR of $20 \mu \mathrm{L}$ contained $0.4 \mu \mathrm{L}$ Phire ${ }^{\circledR}$ Hot Start DNA polymerase, $4 \mu \mathrm{L}$ of Phire ${ }^{\circledR}$ reaction buffer, $0.4 \mu \mathrm{L}$ of each primer (final concentration $0.2 \mathrm{mmol}$ ), $1 \mu \mathrm{L}$ of DNA template, $0.4 \mu \mathrm{L}$ of DNTP, $0.6 \mu \mathrm{L}$ of $3 \%$ DMSO, and $12.8 \mu \mathrm{L}$ nucleasefree water. Samples which were unsuccessful with scyphozoan specific mtCOI primers were additionally amplified using Folmer universal COI primers (Folmer et al., 1994) with $5 \mathrm{~min}$ at $98^{\circ} \mathrm{C}$, followed by 40 cycles of $10 \mathrm{~s}$ at $60^{\circ} \mathrm{C}, 1 \mathrm{~min}$ at $72^{\circ} \mathrm{C}$ and finally $5 \mathrm{~min}$ at $72^{\circ} \mathrm{C}$. The use of universal primers was aimed as a control for DNA extraction and PCR to detect the identity of the specimens that were unsuccessful with mtCOI primers before. PCR products were purified using Illustra GFX PCR DNA and gel band purification kit following the cleaning procedure recommended by the manufacturer (Illustra GFX PCR DNA and Gel Band Purification Kit). Sequencing was carried out by Eurofins Sequencing Service (Eurofins, Germany). The resulting nucleotide sequence electropherograms were checked by eye for poor base calls and sequence quality using Chromas Lite 2.1 (Technelysium Pty Ltd). The high-quality sequences were assembled using BioEdit software (Hall, 1999).

As the genus Aurelia contains several cryptic species, GenBank sequences of each species published in Dawson et al. (2005) were combined with our sequences and aligned with the MAFFT online service (Katoh et al., 2019). The sequences were aligned using Q-INS-i strategy, which takes RNA secondary structure into account, and gap-opening penalty of 1.53 and gap extension penalty of 0.123 . The alignments were visually checked, identical sequences were removed, and poorly aligned regions were excluded prior to the analyses. The alignments are available on request. Bayesian phylogenetic analysis was performed with MrBayes 3.2.7a (Ronquist et al., 2012). Two independent runs with four Markov chains and 1600000 generations were carried out (average standard deviation of split frequencies 0.0094). The model was not chosen prior to the analysis but sampled across the GTR model space with gamma-distributed rate variation across sites and a proportion of invariable sites. The resulting estimates (e.g., tree topology) were posterior probability weighted averages of the models. Maximum likelihood bootstrap support values 


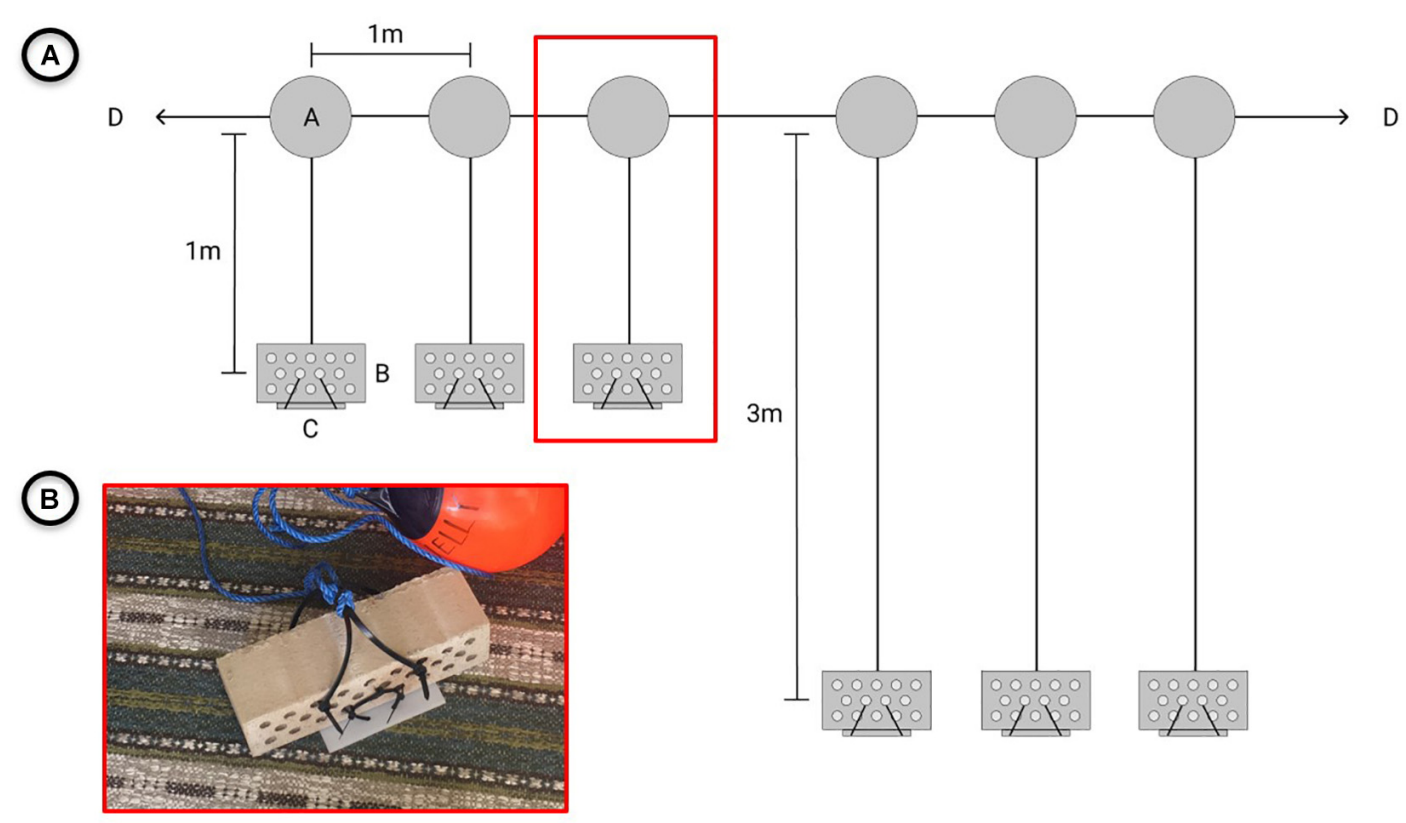

FIGURE 2 | Rig and settling plate design (A) Rig components (A: float, B: brick, C: settling plate, and D: mooring points) as they were aligned and deployed at one and three meter water depth at MAU1, SLE1 and TBS and (B) Settling plate attached to a brick.

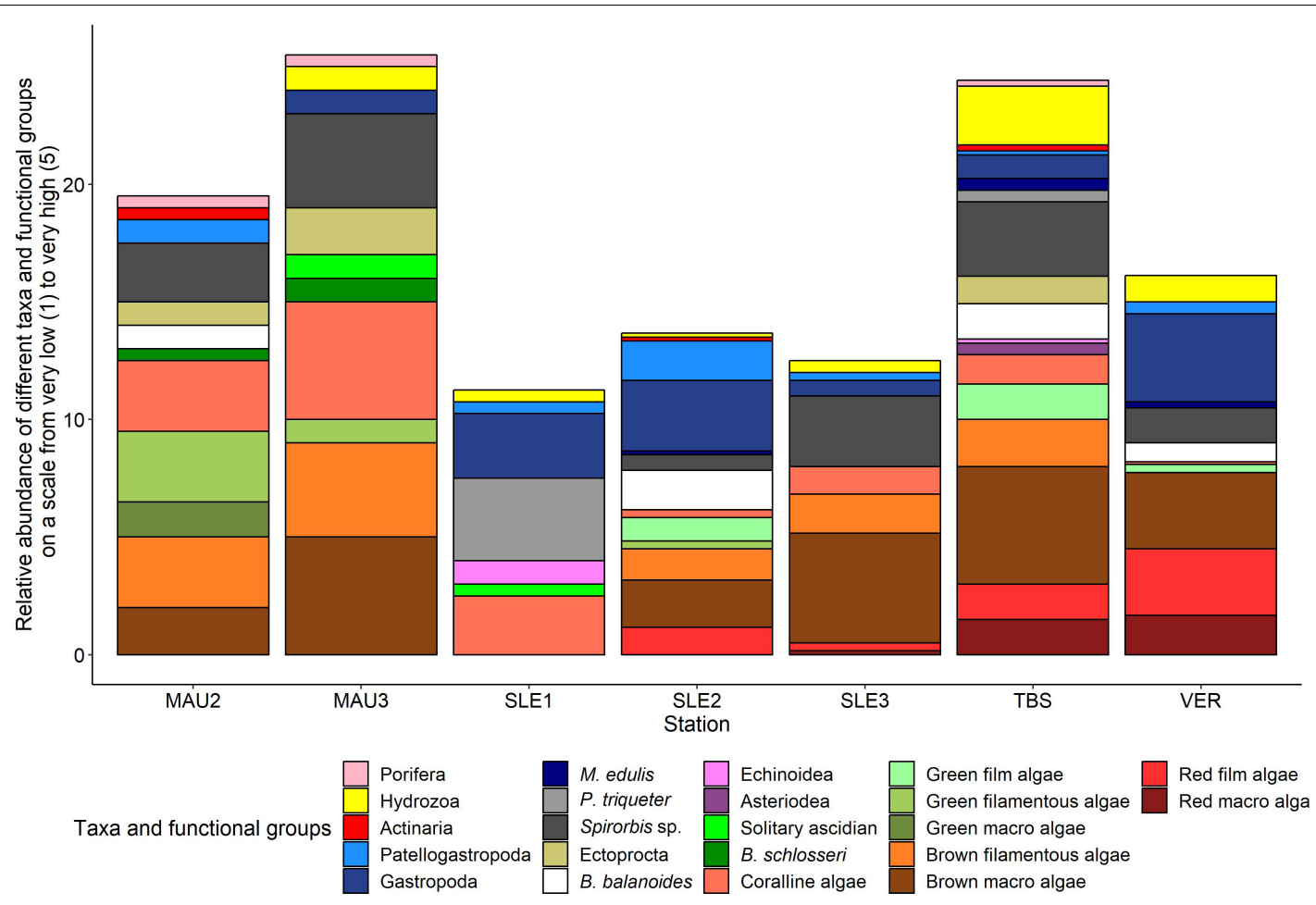

FIGURE 3 | Relative abundance of different taxa and functional groups on a scale from very low (1) to very high (5) at MAU2, MAU3, SLE1, SLE2, SLE3, TBS, and VER. 
were calculated from 1000 replicates, using GARLI 2.0.1019 (Zwickl, 2006) with jModelTest 0.1.1 (Posada, 2008) AICc criterion selected model (TIM2 $+\mathrm{I}+\mathrm{G})$. The sequences reported in this paper have been deposited in the European Molecular Biology Laboratory (EMBL) Nucleotide Sequence Database.

\section{Statistics}

A principal component analysis (PCA) based on the fouling coverage (\%), was computed in $\mathrm{R}$ (version 3.5.2) using nonmetric Multidimensional Scaling with the metaMDS function in the R package Vegan (Oksanen, 2015). One settling plate replicate was lost from both MAU1 and SLE1 and was thus not included into the analysis. One of the $1 \mathrm{~m}$ replicates at TBS1 experienced substantial damage due to contact with the seafloor during low tide which affected the colonization patterns. This replicate was excluded from PCA analysis. A PCA plot was generated in R using the loading scores of the "points"-object from the PCA. The segments representing the variable loading scores were generated using the "species"-object loading scores. A layer encircling the different observations of each station and a layer for each depth ( 1 and $3 \mathrm{~m}$ ) were added.

\section{RESULTS}

\section{Field Survey \\ Polyp Counts}

The field survey provided a qualitative overview of the Aurelia sp. polyp colonies within and outside Trondheimsfjorden (Table 1). Polyps were found on 70 substrata of varying material types at nine stations along the longitudinal gradient within and outside Trondheimsfjorden. The polyps on MAU3, SLE2, SLE3, TBS, and VER were observed in bays with macroalgae canopies at $0.2-$ $1.5 \mathrm{~m}$ depth on the down facing side of rocks, a concrete slab, and two occurrences on kelp (MAU3). The polyps on MAU1 (53 polyps, 24 strobile) and MAU2 (103 polyps) were observed inside rock cracks at $0.2-2 \mathrm{~m}$ depth on the down facing side. The polyps on SLE1 were observed in a sheltered lagoon at 1-2 $\mathrm{m}$ depth on the down facing side and inside bricks (14 polyps, 5 strobile), cinder blocks (71 polyps) and a glass bottle (4 polyps, 3 strobile), on an iron plate ( 24 polyps), and on rocks ( 47 polyps, 5 strobile). Strobile were only found earlier in the season from mid-March to early May but were no longer present in late May.

\section{Characterization of Substratum Type and Epibiont Communities}

The hoop plots provided an overview on the relative abundance of different taxa and functional groups on a scale from very low (1) to very high (5) at each station (Figure 3). MAU2 and MAU3 were similar in species composition but differed in relative abundance. Both stations were characterized by Spirorbis sp., green filamentous algae, brown macroalgae, and brown filamentous algae. The stations TBS and MAU2-3 showed similarities in composition and abundance characterized by Hydrozoa, Spirorbis sp., and brown macroalgae while at MAU23 , red film algae and red macroalgae were additionally of importance. VER was characterized by Gastropoda, brown macroalgae, red film algae and red macroalgae. SLE1 was most distinct from all other stations characterized by Gastropoda, $P$. triqueter and coralline algae while SLE2 was characterized by Gastropoda, small amounts of brown filamentous algae and brown macroalgae. At SLE3, Spirorbis sp. and brown macroalgae were most common.

\section{Settling Plate Survey Polyp Counts}

The settled Aurelia sp. polyp abundance varied greatly between stations, but also between the settling plate units with one standard deviation exceeding the mean (Table 2). The $3 \mathrm{~m}$ SLE1 settling plates had the highest number of settled Aurelia sp. polyps with an average of $1.2( \pm 0.7)$ polyps $\mathrm{cm}^{-2}$, while the $1 \mathrm{~m}$ SLE1 settling plates had no polyps. A $1 \mathrm{~m}$ TBS settling plates had an average of $0.4( \pm 0.5)$ polyps $\mathrm{cm}^{-2}$ and $3 \mathrm{~m}$ TBS settling plates had an average of $0.12( \pm 0.07)$ polyps $\mathrm{cm}^{-2}$. There were no polyps on the MAU1 settling plates, both at 1 and $3 \mathrm{~m}$.

\section{Characterization of Substratum Type and Epibiont Communities}

The abundance of polyps on the different substrata were highest on the PVC plate material at all depths and all locations, followed

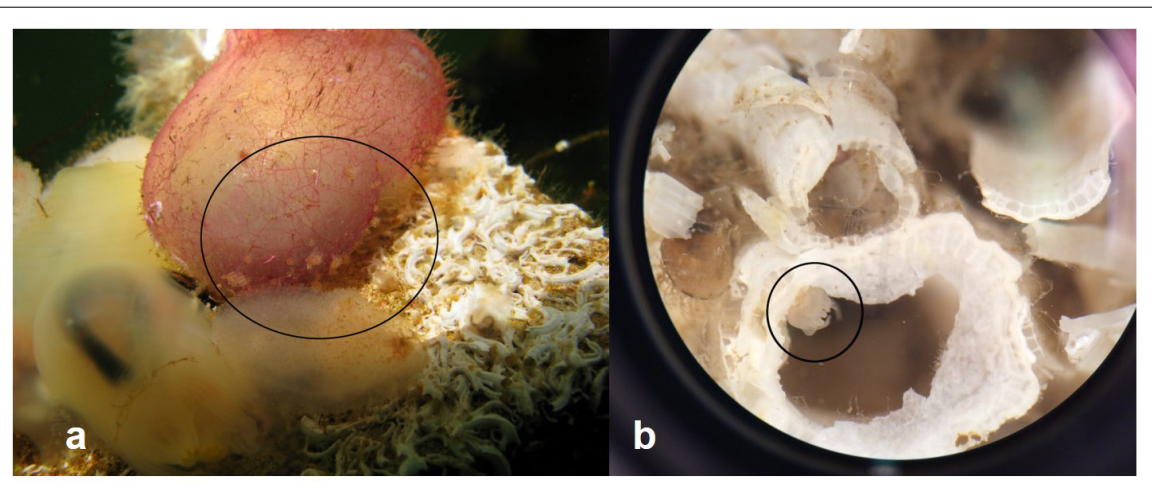

FIGURE 4 | (a) Polyp on Ascidia mentula from SLE1 settling plate. Other species on the plate are Pomatoceros triqueter, Ciona intestinalis, and hydrozoans. (b) Polyp on barnacle shell of dead Balanus balanoides from TBS settling plate. Polyps are encircled. Photos: M. E. Rekstad. 
by a colonization of polyps as epibionts on the ascidian Ascidia mentula (solitary ascidian) at SLE1 (Figure 4a) and on barnacle shells of Balanus balanoides at TBS (Figure $\mathbf{4 b}$ ). A few polyps were present on the solitary ascidian Ciona intestinalis at SLE1 and on shells of the blue mussel Mytilus edulis at TBS.

The PCA plot of fouling coverage shows a clear separation of the three settling plate locations with higher polyp abundances occurring on plates with higher percent coverage of fouling organisms (Figure 5). TBS represents one cluster that shows distinct separation from the other two stations on dimension 1 caused by the variable "Debris mix" (Figure 5A). On dimension 2, MAU1 and SLE1 settling plates show a clear separation. The MAU1 points are pulled mainly by the compound ascidian Botryllus schlosseri, Bryozoa, the tube-dwelling amphipod Jassa falcata. The SLE1 points are pulled by the ascidian A. mentula, C. intestinalis, M. edulis, and P. triqueter variables.

Aurelia sp. polyp abundance on each settling plate replicates is provided using four different abundance levels: $0,>100$, $>200$, and $>300$ polyps per plate (Figure 5B). The $1 \mathrm{~m}$ settling

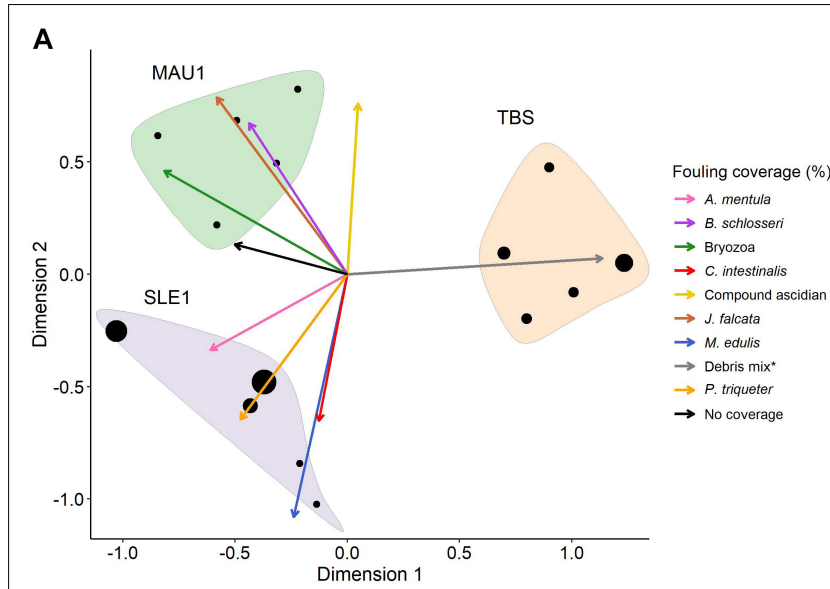

B

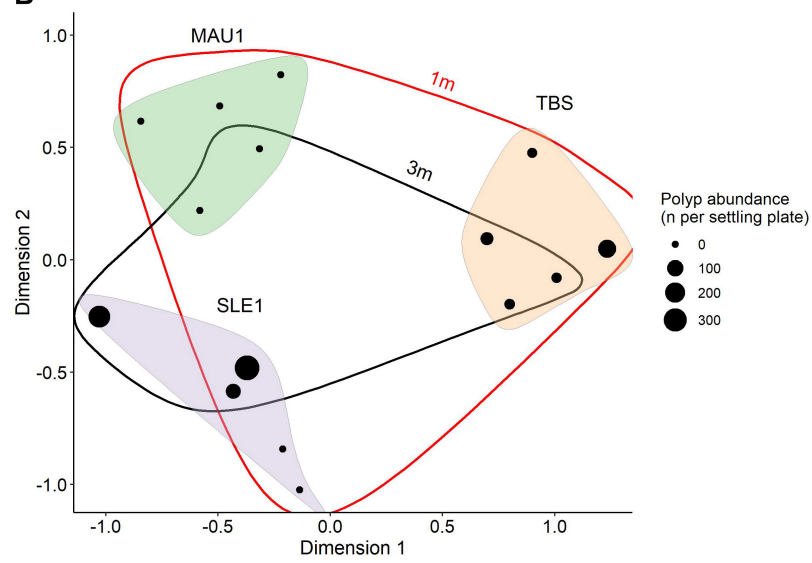

FIGURE 5 | Principle component analysis (PCA): (A) Fouling coverage (\%) on the settling plates where dots represent the settling plate replicates, vectors represent the epibiont coverage (\%) loading scores from PCA and asterix indicates "Debris mix" including dead B. balanoides and juvenile M. edulis. (B) Polyp abundance (n per settling plate) where dot size increases with high polyp abundance $(n)$, each location is encircled. plate replicates are encircled in red while the $3 \mathrm{~m}$ replicates are encircled in black. The $1 \mathrm{~m}$ circle includes most of the $3 \mathrm{~m}$ replicates indicating that the variation between the two depths were small and that the variation of fouling coverage was higher at $1 \mathrm{~m}$.

\section{Molecular Species Identification of Polyps}

The 193 polyp specimens sampled (121 from field and 72 from settling plates), provided 119 (72 from the field and 57 from the settling plates) Aurelia mtCOI sequences including 41 unique sequences (Figure 6). In Blast search, 14 of the field collected specimens matched together with Aurelia sp. sequence from Turkey, Black Sea with $99-100 \%$ match and $99.8 \%$ query coverage (HQ913940.1). These specimens were collected from Sletvik and Verdal. Forty-eight of the specimens collected from in field matched (99-100\%) together with Aurelia aurita sequence collected from United Kingdom (KJ026293.1; KJ026305.1; KJ026309.1; KJ026319.1; KJ026339.1; KX691612.1), Chile (KY564361.1) or Sweden (MG935022.1). The 49 field collected specimens with unsuccessful PCR while using scyphozoan specific primers, were re-run using universal COI primers thus resulting in 10 good-quality sequences which matched Ascophyllum nodosum (brown macroalgae; MH309539.1; MH309680.1), Alteromonas sp. (bacteria; CP018023.1), Dexamine thea (amphipod; KT209105.1), Glycinde armigera (polychete; KT989325.1), Ancylis badiana (moth; KM573396.1). From the specimens collected from the settling plates, one of the sequences from TBS matched together with Aurelia sp. sequence from Turkey, Black Sea with 100\% match and 99.8\% coverage, respectively (HQ913940.1). The remaining 56 of the sequences matched (99-100\% with 99.5-100\% coverage) together with Aurelia aurita sequence collected from United Kingdom (KJ026285.1; KJ026310.1; KJ026350.1; KJ026305.1; KJ026309.1; KJ026319.1; KJ026339.1; KX691612.1), Chile (KY564361.1) or Sweden (MG935022.1). All Aurelia polyp sequences in this study clustered together with the Aurelia aurita from North-East USA and Scandinavia (Dawson et al., 2005).

\section{DISCUSSION}

\section{Aurelia sp. Polyps in Trondheimsfjorden}

Aurelia sp. polyps occurred on natural substrata in the littoral zones of Trondheimsfjorden along a longitudinal gradient from the outer to the inner part of Trondheimsfjorden. To complement in situ field observations, a settling plate approach was used to study the occurrence of freshly settled Aurelia sp. polyps on artificial substrata (Gröndahl, 1988a; Watanabe and Ishii, 2001; van Walraven et al., 2016).

Since accuracy of polyp identification based on morphological features is limited (Holst, 2012; van Walraven et al., 2016), molecular species identification of polyps from the field and settling plates was performed. From the entire set of samples, 119 polyps were successfully amplified using scyphozoanspecific COI primers, and returned as matches of Aurelia sp. or Aurelia aurita clustering together with the Aurelia aurita 


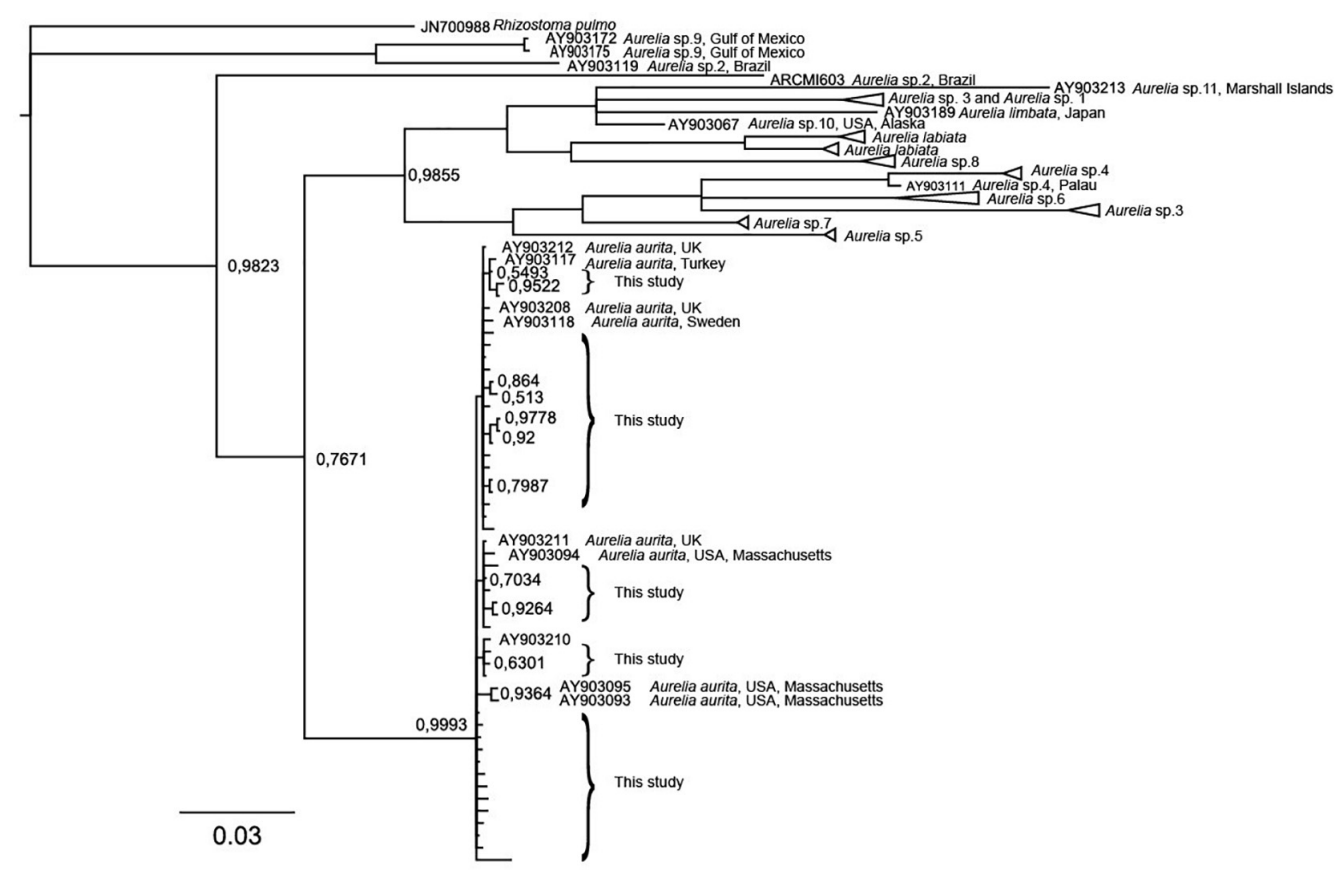

FIGURE 6 | Bayesian consensus tree of partial COI gene sequences of Aurelia spp. demonstrating the variation of polyps sequenced in this study. Values on branches are posterior probabilities.

from North-East USA and Scandinavia (Dawson et al., 2005). Thus, H1 hypothesizing that Aurelia sp. polyps are common fouling organisms in Trondheimsfjorden could be confirmed. However, some of the specimens morphologically identified as Aurelia polyps were not successfully amplified using scyphozoanspecific COI primers but were instead identified as e.g., brown macroalgae and polychetes while using universal primers. This demonstrates the need of using molecular methods to accurately identify scyphozoan polyps.

Aurelia sp. polyp abundance on settling plates in Trondheimsfjorden ranged from 0.12 to 1.2 polyps $\mathrm{cm}^{-2}$. This abundance is low compared to other studies where i.e., abundances of 12-45 polyps $\mathrm{cm}^{-2}$ were noted on a wreck in the Adriatic Sea (Di Camillo et al., 2010) and 6-40 polyps $\mathrm{cm}^{-2}$ occurred on artificial substrata in Gullmar Fjord (Hernroth and Gröndahl, 1983). The timing of the different life stages of Aurelia sp. varies considerably with region (Lucas et al., 2012). The timing of polyp settlement observed in September in Trondheimsfjorden matches the life cycle reported for A. aurita in Gullmarfjorden at the Swedish west coast (Gröndahl, 1988a) where polyps settled in the period from August to October. Apart from the newly settled polyps on the plates, field observations of Aurelia sp. polyps/strobila along the longitudinal gradient at the Trondheimsfjorden shoreline were only made from March to May. Strobilation was observed in the field during this period (Rekstad, Borgersen, Aberle pers. observation). Given the fact that polyps occurred prior to the annual settling period, Aurelia sp. polyps observed during field observations were likely overwintering polyps that settled the year before. Despite several trials using vertical net deployments in different areas of the fjord, ephyrae were not sampled during any occassion. However, observations of Aurelia sp. polyps during different seasons indicate a year-round occurrence in Trondheimsfjorden (Brewer, 1989; Holst and Jarms, 2010; van Walraven et al., 2020).

\section{Macrohabitats of Aurelia sp. Polyps}

The hypothesis that sheltered and exposed habitats serve as suitable environments for Aurelia sp. polyps was supported by the occurrence of Aurelia sp. polyps in the inter- and subtidal zones from 0.1 to $3 \mathrm{~m}$ depth along a longitudinal gradient in Trondheimsfjorden. Retention areas and sheltered environments with reduced current velocity and wave action at MAU3, SLE1-3, TBS, and VER were found to be suitable habitats. Macroalgae canopies and surfaces underneath dense layers of macroalgae and attached to tide pool rocks were also found to be a suitable substratum for Aurelia sp. polyps. In the intertidal, polyps occurred even in areas where they remained partly emerged during low tide and where they were subject to a high variability of temperature, salinity and oxygen. In agreement with previous studies showing a high tolerance of polyps to salinity (Holst and Jarms, 2010) and oxygen changes (Ishii et al., 2008; Ishii and Katsukoshi, 2010), Aurelia sp. polyps in Trondheimsfjorden seem also to cope with such wide ranges in abiotic conditions. The positive impact of macroalgae canopies on Aurelia sp. polyp settlement could be related to a trapping effect of spawning medusae in shallow coastal areas thus promoting the release of planulae in close vicinity (Östman, 1997). However, in contrast to the study of Östman (1997) where Aurelia sp. polyps settled as epibionts on Laminaria saccharina, the polyps found in this study did 
usually not directly settle on macroalgae thalli but rather on the substratum underneath.

In contrast, sites with stronger exposure to wave action and currents as well as low fouling coverage (MAU1) showed a low settlement and occurrence of polyps. The present results point at less favorable conditions for polyp settlement and occurrence at more exposed sites thus leading to a rejection of $\mathrm{H} 2$. This observation is in line with observations from Gullmarfjorden (Sweden) where higher Aurelia sp. polyp abundances were reported from sheltered, shallow areas while deeper and more exposed areas showed lower abundances (Östman, 1997). More sheltered sites might create a better feeding environment for polyps that allow a more effective capturing of food items e.g., copepods, polychete larvae and chaetognaths (Östman, 1997).

\section{Microhabitats of Aurelia sp. Polyps Created by Other Fouling Organisms}

We hypothesized that microhabitats created by other fouling organisms promote a suitable environment for Aurelia sp. polyps. From previous studies there is indication that Aurelia sp. polyps co-exist with other fouling organisms (Feng et al., 2017b) and that polyp settlement is promoted by biogenic hard substrata that provide distinct microhabitats (Lucas et al., 2012; van Walraven et al., 2016).

During the field survey, Aurelia sp. polyps were found especially in environments characterized by a moderate epigrowth with filamentous algae, macroalgae, Spirorbis sp., gastropods and coralline algae (e.g., Lithothamnion sp., Phymatolithon sp.). The settling plate approach pointed at a positive effect of Ascidia mentula, Pomatoceros triqueter and debris of Balanus balanoides on the settlement of Aurelia sp. polyps while Mytilus edulis and Ciona intestinalis inhibited settlement. These results point at the crucial role of microhabitats created by specific fouling organisms promoting the occurrence of Aurelia sp. polyps in situ thus confirming H3 of the present study.

One of the possible causes for a positive effect of $P$. triqueter on polyp settlement might be related to the fact that a suitable microhabitat with crevices and imprints from the tubes are created by the polychete. A. mentula is a solitary ascidian with a cartilaginous body and a leathery tunic cuticle (de Kluijver and Ingalsuo, 2012). The rough and hard surface seemed to promote Aurelia sp. polyps to settle as epibionts on its tunic cuticle while the soft, solitary ascidian C. intestinalis did not serve as a suitable surface for Aurelia sp. polyp settlement.

Previous studies reported on Aurelia sp. polyp settlement attached to shells of M. edulis (Östman, 1997; Miyake et al., 2002; van Walraven et al., 2016). In our study, a settlement in close vicinity to live $M$. edulis could not be observed. M. edulis can scrub substratum surfaces with its foot thus leading to competitive exclusion due to removal of weakly attached fouling organisms i.e., freshly settled Aurelia sp. polyps (Wiegemann, 2005) rather than coexistence with other fouling organisms. Further, the byssus threads of $M$. edulis can create uneven and unstable surfaces that might inhibit Aurelia sp. polyp settlement, a pattern also observed in Tokyo Bay (Ishii and Katsukoshi,
2010) were a clear spatial separation and competition for space of Aurelia sp. polyps and Mytilus galloprovincialis was observed. Further, filter feeders can affect the initial settlement of planulae larvae due to suspension feeding that can lead to a reduction of scyphozoan planulae in the vicinity of e.g., M. edulis, a pattern that is considered as one of the control mechanisms for jellyfish bloom formation (Kuplik et al., 2015).

Further, dead $B$. balanoides had a positive impact on the settlement of Aurelia sp. polyps on the settling plates where polyps settled either on or inside the visible imprints of $B$. balanoides indicating that the inner layer of shells from dead $B$. balanoides provides shelter and can be considered as a suitable microhabitat for Aurelia sp. polyps.

As described earlier for $M$. edulis, fouling organisms can either serve as settling substrate for Aurelia sp. polyps or act as direct competitors for space. That applies for A. mentula, C. intestinalis and $B$. balanoides that are likely to compete with Aurelia sp. polyps during settlement. In addition, filter feeders can affect the initial settlement of planulae larvae related to grazing on scyphozoan planulae, a pattern that is considered as one of the control mechanisms for jellyfish bloom formation (Kuplik et al., 2015).

However, the knowledge on such competitive interactions between Aurelia sp. polyps and other fouling organisms are scarce and future research is needed to fully understand density-driven competition within fouling communities that alter the probability of jellyfish bloom formation.

\section{Occurrence of Aurelia sp. Polyps on Natural and Artificial Surfaces}

In total, 70 different substrata were identified as suitable for Aurelia sp. polyps along the longitudinal gradient in Trondheimsfjorden. It is reported that Aurelia sp. polyps can be found on a variety of natural and artificial substrata usually settling on the downfacing side of e.g., rocks, bricks, cinder blocks, glass, and iron surfaces (van Walraven et al., 2016). Some polyps were also found as on biogenic material e.g., on polychete tubes of $P$. triqueter or the imprints of dead B. balanoides shells. Based on the field observations, no clear preference of Aurelia sp. polyps for natural substrata as opposed to artificial substrata could be observed thus leading to a rejection of $\mathrm{H} 4$.

Similar patterns were observed using the settling plate approach. Here, artificial substrata promoted a successive colonization of fouling organisms throughout the entire deployment period which in turn had a positive impact on Aurelia sp. polyp settlement. Some Aurelia sp. polyps settled on the biogenic material provided by the fouling communities e.g., dead shells of $B$. balanoides or as epibionts on A. mentula. However, most Aurelia sp. polyps settled directly on the PVCplates in the gaps between fouling organisms and on imprints from formerly attached biota. This observation contrasts with data from Kagoshima Bay, Japan (Miyake et al., 2002) where Aurelia sp. polyps only settled on biogenic material e.g., Mytilus shells, solitary ascidians, polychete or amphipod tubes.

In conclusion, the present field study provides new insights into the occurrence and habitat characteristics of local 
Aurelia sp. polyp populations in the inter- and sub-tidal areas of a high-latitude fjord ecosystem. Aurelia sp. polyps on a variety of natural and artificial substrata while specifically sheltered littoral zones along the coast within and outside Trondheimsfjorden (e.g., bays with macroalgae canopies, areas with low exposure to currents and wave action) were found to be suitable habitats for Aurelia sp. polyps.

Based on in situ observations and settling plate deployments, interactions between Aurelia sp. polyps and other fouling organisms were analyzed thus providing insights into habitat structure, microhabitat characteristics and potential impacts of interspecific competition within fouling communities. Especially interactions between Aurelia sp. polyps and coralline algae, the tube-building polychete Pomatoceros triqueter, the solitary ascidian Ascidia mentula, the blue mussel Mytilus edulis and the barnacle Balanus balanoides were analyzed.

Aurelia sp. is one of the main jellyfish species that forms distinct seasonal blooms in Trondheimsfjorden during summer. Based on the knowledge gained from this study, it is likely that blooms of Aurelia sp. originate substantially from local polyp seed populations in the inter- and sub-tidal areas of the fjord. The findings on local polyp populations in this specific fjord can be applied to other high-latitude fjord ecosystems thus allowing more advanced ecosystem management strategies for fjord ecosystems and allow more reliable jellyfish bloom predictions for semi-enclosed marine systems worldwide.

\section{DATA AVAILABILITY STATEMENT}

The authors acknowledge that the data presented in this study must be deposited and made publicly available in an acceptable

\section{REFERENCES}

Abramoff, M. D., Magalhaes, P. J., and Ram, S. J. (2004). Image processing with ImageJ. Biophotonics Int. 11, 36-42.

Arai, M. N. (1997). A Functional Biology of Scyphozoa, Vol. 6. London: Chapman \& Hall. doi: 10.1007/978-94-009-1497-1

Bakken, T. (2000). “Topografien i Trondheimsfjorden,” in Trondheimsfjorden, Vol. 6, eds E. Sakshaug and J.-A. Sneli (Trondheim: Tapir Forlag), 12-18.

Brewer, R. H. (1984). The influence of the orientation, roughness, and wettability of solid surfaces on the behavior and attachment of planulae of Cyanea sp. (Cnidaria: Scyphozoa). Biol. Bull. 166, 11-21. doi: 10.2307/1541426

Brewer, R. H. (1989). The annual pattern of feeding, growth, and sexual reproduction in Cyanea sp. (Cnidaria: Scyphozoa) in the Niantic River estuary, Connecticut. Biol. Bull. 176, 272-281. doi: 10.2307/1541985

Dawson, M. N., Sen Gupta, A., and England, M. H. (2005). Coupled biophysical global ocean model and molecular genetic analyses identify multiple introductions of cryptogenic species. Proc. Natl. Acad. Sci. U.S.A. 102, 1196811973. doi: 10.1073/pnas.0503811102

de Kluijver, M. J., and Ingalsuo, S. S. (2012). Macrobenthos of the North Sea Tunicata. A. mentula. Available online at: http://species-identification.org/ index.php? groep $=$ Tunicates\&selectie $=17$ \&hoofdgroepen_pad $=\% 2 \mathrm{C} 1 \% 2 \mathrm{C} 17$

Di Camillo, C. G., Betti, F., Bo, M., Martinelli, M., Puce, S., and Bavestrello, G. (2010). Contribution to the understanding of seasonal cycle of Aurelia aurita (Cnidaria: Scyphozoa) scyphopolyps in the northern Adriatic Sea. J. Mar. Biol. Assoc. U. K. 90, 1105-1110. doi: 10.1017/S0025315409000848

Doney, S. C., Ruckelshaus, M., Duffy, J. E., Barry, J. P., Chan, F., English, C. A., et al. (2012). Climate change impacts on marine ecosystems. Ann. Rev. Mar. Sci. 4, 11-37. doi: 10.1146/annurev-marine-041911-111611 repository, prior to publication. Frontiers cannot accept a manuscript that does not adhere to our open data policies. The sequences reported in the study have been deposited in the European Nucleotide Archive repository with accession numbers: OU018801-OU018842 (http://www.ebi.ac.uk/ena/ data/view/OU018801-OU018842).

\section{AUTHOR CONTRIBUTIONS}

The field study was conceptualized and designed by all coauthors. MR, NA and ÅB conducted the field work. MR and SM performed the molecular analyses. MR and NA wrote the manuscript with contributions from SM and $\AA \mathrm{B}$. SM and NA provided funding acquisition, supervision and guidance on data analysis, interpretation, and manuscript writing.

\section{FUNDING}

This project was funded by the European Union's Horizon 2020 Research and Innovation Programme (Grant agreement no. 774499) as part of GoJelly (work package 2: "Driving mechanisms and predictions of jellyfish blooms").

\section{ACKNOWLEDGMENTS}

We are grateful to Sabine Holst for fruitful discussions and support. Jack Laverick is thanked for his input on statistical analyses.

Dong, Z. (2018). "Blooms of the moon jellyfish Aurelia: causes, consequences and controls," in World Seas: An Environmental Evaluation, 2nd Edn, ed. C. Sheppard (Cambridge, MA: Academic Press), 163-171. doi: 10.1016/B978-012-805052-1.00008-5

Doyle, T. K., Hays, G. C., Harrod, C., and Houghton, J. D. R. (2014). "Ecological and societal benefits of jellyfish," in Jellyfish Blooms, Vol. 6, eds K. A. Pitt and C. H. Lucas (Dordrecht: Springer Netherlands), 105-127. doi: 10.1007/978-94007-7015-7_5

Duarte, C. M., Pitt, K. A., Lucas, C. H., Purcell, J. E., Uye, S. I., Robinson, K., et al. (2013). Is global ocean sprawl a cause of jellyfish blooms? Front. Ecol. Environ. 11, 91-97. doi: 10.1890/110246

Feng, S., Lin, J. N., Sun, S., and Zhang, F. (2017a). Artificial substrates preference for proliferation and immigration in Aurelia aurita (s. 1.) polyps. Chin. J. Oceanol. Limnol. 35, 153-162. doi: 10.1007/s00343-016-5230-y

Feng, S., Wang, S. W., Zhang, G. T., Sun, S., and Zhang, F. (2017b). Selective suppression of in situ proliferation of scyphozoan polyps by biofouling. Mar. Pollut. Bull. 114, 1046-1056. doi: 10.1016/j.marpolbul.2016.10.062

Folmer, O., Black, M., Hoeh, W., Lutz, R., and Vrijenhoek, R. (1994). DNA primers for amplification of mitochondrial Cytochrome C oxidase subunit I from diverse metazoan invertebrates. Mol. Mar. Biol. Biotechnol. 3, 294-299.

Granhag, L. M., Majaneva, S., and Friis Møller, L. G. (2012). First recordings of the ctenophore Euplokamis sp. (Ctenophora, Cydippida) in Swedish coastal waters and molecular identification of this genus. Aquat. Inv. 7, 455-463. doi: 10.3391/ai.2012.7.4.002

Graham, W. M., Gelcich, S., Robinson, K. L., Duarte, C. M., Brotz, L., Purcell, J. E., et al. (2014). Linking human well-being and jellyfish: ecosystem services, impacts, and societal responses. Front. Ecol. Environ. 12, 515-523. doi: 10.1890/ 130298 
Gröndahl, F. (1988a). A comparative ecological study on the scyphozoans Aurelia aurita, Cyanea capillata and C. lamarckii in the Gullmar Fjord, western Sweden, 1982 to 1986. Mar. Biol. 97, 541-550. doi: 10.1007/BF00391050

Gröndahl, F. (1988b). Interactions between polyps of Aurelia aurita and planktonic larvae of scyphozoans- an experimental study. Mar. Ecol. Prog. Ser. 45, 87-93. doi: 10.3354/meps045087

Hall, T. A. (1999). BioEdit: a user-friendly biological sequence alignment editor and analysis program for Windows 95/98/NT. Nucleic Acids Symp. Ser. 41, 95-98.

Halsband, C., Majaneva, S., Hosia, A., Emaus, P. A., Gaardsted, F., Zhou, Q., et al. (2018). Jellyfish summer distribution, diversity and impact on fish farms in a Nordic fjord. Mar. Ecol. Prog. Ser. 591, 267-279. doi: 10.3354/meps 12274

Hernroth, L., and Gröndahl, F. (1983). On the biology of Aurelia aurita (L) 1. Release and growth of Aurelia aurita (L) ephyrae in Gullmar Fjord, Western Sweden, 1982-83. Ophelia 22, 189-199. doi: 10.1080/00785326.1983.104 26595

Hoehn, D. P., Lucas, C. H., and Thatje, S. (2017). Respiratory response to temperature of three populations of Aurelia aurita polyps in northern Europe. PLoS One 12:e0177913. doi: 10.1371/journal.pone.0177913

Holst, S. (2012). Morphology and development of benthic and pelagic life stages of North Sea jellyfish (Scyphozoa, Cnidaria) with special emphasis on the identification of ephyra stages. Mar. Biol. 159, 2707-2722. doi: 10.1007/s00227012-2028-0

Holst, S., and Jarms, G. (2007). Substrate choice and settlement preferences of planula larvae of five Scyphozoa (Cnidaria) from German Bight, North Sea. Mar. Biol. 151, 863-871. doi: 10.1007/s00227-006-0530-y

Holst, S., and Jarms, G. (2010). "Effects of low salinity on settlement and strobilation of scyphozoa (Cnidaria): is the lion's mane Cyanea capillata (L.) able to reproduce in the brackish Baltic Sea?" in Jellyfish Blooms: New Problems and Solutions, Vol. 6, eds J. E. Purcell and D. L. Angel (Dordrecht: Springer Netherlands), 53-68. doi: 10.1007/978-90-481-9541-1_5

Hoover, R. A., and Purcell, J. E. (2008). "Substrate preferences of scyphozoan Aurelia labiata polyps among common dock-building materials," in Jellyfish Blooms: Causes, Consequences, and Recent Advances, eds K. A. Pitt and J. E. Purcell (Dordrecht: Springer), 259-267. doi: 10.1007/978-1-4020-97 49-2_18

Hosia, A., Falkenhaug, T., and Naustvoll, L. J. (2014). Trends in abundance and phenology of Aurelia aurita and Cyanea spp. at a Skagerrak location, 1992-2011. Mar. Ecol. Prog. Ser. 498, 103-115. doi: 10.3354/meps 10619

Ishii, H., and Katsukoshi, K. (2010). Seasonal and vertical distribution of Aurelia aurita polyps on a pylon in the innermost part of Tokyo Bay. J. Oceanogr. 66, 329-336. doi: 10.1007/s10872-010-0029-5

Ishii, H., Ohba, T., and Kobayashi, T. (2008). Effects of low dissolved oxygen on planula settlement, polyp growth and asexual reproduction of Aurelia aurita. Plankton Benthos Res. 3, 107-113. doi: 10.3800/pbr.3.107

Jacobson, P. (1983). Physical oceanography of the Trondheimsfjord. Geophys. Astrophys. Fluid Dyn. 26, 3-26. doi: 10.1080/03091928308221761

Janssen, H., Augustin, C. B., Hinrichsen, H. H., and Kube, S. (2013). Impact of secondary hard substrate on the distribution and abundance of Aurelia aurita in the western Baltic Sea. Mar. Pollut. Bull. 75, 224-234. doi: 10.1016/j.marpolbul. 2013.07.027

Katoh, K., Rozewicki, J., and Yamada, K. D. (2019). MAFFT online service: multiple sequence alignment, interactive sequence choice and visualization. Brief Bioinform. 20, 1160-1166. doi: 10.1093/bib/bbx108

Kuplik, Z., Kerem, D., and Angel, D. L. (2015). Regulation of Cyanea capillata populations by predation on their planulae. J. Plankton Res. 37, 1068-1073. doi: $10.1093 /$ plankt/fbv064

Licandro, P., Blackett, M., Fischer, A., Hosia, A., Kennedy, J., Kirby, R. R., et al. (2015). Biogeography of jellyfish in the North Atlantic, by traditional and genomic methods. Earth Syst. Sci. 7, 173-191. doi: 10.5194/essd-7-1732015
Lucas, C. H. (2001). Reproduction and life history strategies of the common jellyfish, Aurelia aurita, in relation to its ambient environment. Hydrobiologia 451, 229-246. doi: 10.1023/A:1011836326717

Lucas, C. H., Graham, W. M., and Widmer, C. (2012). Jellyfish life histories: role of polyps in forming and maintaining scyphomedusa populations. Adv. Mar. Biol. 63, 133-196. doi: 10.1016/B978-0-12-394282-1.00003-X

Makabe, R., Furukawa, R., Takao, M., and Uye, S. I. (2014). Marine artificial structures as amplifiers of Aurelia aurita blooms: a case study of a newly installed floating pier. J. Oceanogr. 70, 447-455. doi: 10.1007/s10872-0140249-1

Marcus, N. H. (1998). Minireview: the importance of benthic-pelagic coupling and the forgotten role of life cycles in coastal aquatic systems. Limnol. Oceanogr. 43, 763-768. doi: 10.4319/lo.1998.43.5.0763

Marques, R., Cantou, M., Soriano, S., Molinero, J. C., and Bonnet, D. (2015). Mapping distribution and habitats of Aurelia sp polyps in Thau lagoon, northwestern Mediterranean Sea (France). Mar. Biol. 162, 1441-1449. doi: 10.1007/ s00227-015-2680-2

Miyake, H., Terazaki, M., and Kakinuma, Y. (2002). On the polyps of the common jellyfish Aurelia aurita in Kagoshima Bay. J. Oceanogr. 58, 451-459. doi: 10. 1023/A:1021628314041

Oksanen, J. (2015). Multivariate Analysis of Ecological Communities in R: Vegan Tutorial.

Östman, C. (1997). Abundance, feeding behaviour and nematocysts of scyphopolyps (Cnidaria) and nematocysts in their predator, the nudibranch Coryphella verrucosa (Mollusca). Hydrobiologia 355, 21-28. doi: 10.1023/A:1003065726381

Posada, D. (2008). jModelTest: Phylogenetic model averaging. Mol. Biol. Evol. 25, 1253-1256. doi: 10.1093/molbev/msn083

Ronquist, F., Teslenko, M., and van der Mark, P. (2012). MrBayes 3.2: efficient Bayesian phylogenetic inference and model choice across a large model space. Syst. Biol. 61, 539-542. doi: 10.1093/sysbio/sys029

Sakshaug, E., and Sneli, J. A. (2000). Trondheimsfjorden. Trondheim: Tapir Forlag.

Tokle, N., and Sakshaug, E. (2000). "Dyreplanktonet," in Trondheimsfjorden, ed. E. Sakshaug (Trondheim: Tapir Forlag), 103-109.

van Walraven, L., Driessen, F., van Bleijswijk, J., Bol, A., Luttikhuizen, P. C., Coolen, J. W. P., et al. (2016). Where are the polyps? Molecular identification, distribution and population differentiation of Aurelia aurita jellyfish polyps in the southern North Sea area. Mar. Biol. 163:172. doi: 10.1007/s00227-0162945-4

van Walraven, L., van Bleijswijk, J., and van der Veer, H. W. (2020). Here are the polyps: in situ observations of jellyfish polyps and podocysts on bivalve shells. PeerJ 8:e9260. doi: 10.7717/peerj.9260

Watanabe, T., and Ishii, H. (2001). In situ estimation of ephyrae liberated from polyps of Aurelia aurita using settling plates in Tokyo Bay, Japan. Hydrobiologia 451, 247-258. doi: 10.1023/A:1011856929443

Wiegemann, M. (2005). Adhesion in blue mussels (Mytilus edulis) and barnacles (Balanus sp.): mechanisms and technical applications. Aquat. Sci. 67, 166-176. doi: 10.1007/s00027-005-0758-5

Zwickl, D. J. (2006). Genetic Algorithm Approaches for the Phylogenetic Analysis of Large Biological Sequence Datasets Under the Maximum Likelihood Criterion. Austin, TX: The University of Texas at Austin.

Conflict of Interest: The authors declare that the research was conducted in the absence of any commercial or financial relationships that could be construed as a potential conflict of interest.

Copyright (C) 2021 Rekstad, Majaneva, Borgersen and Aberle. This is an open-access article distributed under the terms of the Creative Commons Attribution License (CC BY). The use, distribution or reproduction in other forums is permitted, provided the original author(s) and the copyright owner(s) are credited and that the original publication in this journal is cited, in accordance with accepted academic practice. No use, distribution or reproduction is permitted which does not comply with these terms. 